\title{
Frequent genetic defects in long-term survivors for more than 26 years in the absence of antiretroviral therapy in Korea: its association with ginseng treatment
}

\author{
Young-Keol Cho*, Ba-Reum Kim, Jung-Eun Kim \\ From Frontiers of Retrovirology: Complex retroviruses, retroelements and their hosts \\ Cambridge, UK. 16-18 September 2013
}

\section{Background}

The association between long-term nonprogressors (LTNPs) and genetic defects in HIV-1 is not clear because of paucity of genetic defects in LTNPs. To date, there is only a report on gross deletion in 2 genes of HIV-1. Ginseng has been used as the premier medicinal plant for a thousand years [1]. Korean red ginseng (KRG) has been applied to HIV-1 infected patients since November 1991 [2]. We have found that most HIV-1 infected patients treated with KRG for a significant period slowly progressed to AIDS and revealed a high frequency of genetic defects.

\section{Materials and methods}

A total of 250 individuals were diagnosed with HIV-1 infection in Korea before 1993. Among the 250 individuals, we selected all who remain healthy for $>18$ years in the absence of antiretroviral therapy. They were four individuals $(26,25,21$, and 18 years from diagnosis). One patient who was diagnosed with HIV-1 in 1992 took a little KRG - less than 1,000 g. To investigate whether LTNPs are associated with genetic defects, we amplified near fulllength HIV-1 sequences in 10 overlapping fragments $(0.8$ to $1.4 \mathrm{~kb}$ ) using nested PCR with peripheral blood mononuclear cells. We compared the data with that in 4 control patients. Amount of KRG supplied was significantly higher in LTNPs $(21,767-8,866 \mathrm{~g})$ than 1,250-1,304 $\mathrm{g}$ in controls $(\mathrm{P}<0.01)$.

\section{Results}

We obtained 1,339 and 386 PCR amplicons over 20 years in LTNPs and over 10 years in controls, respectively.

\footnotetext{
Microbiology, University of Ulsan College of Medicine, SEOUL, Republic of
} Korea

(C) 2013 Cho et al; licensee BioMed Central Ltd. This is an Open Access article distributed under the terms of the Creative Commons Attribution License (http://creativecommons.org/licenses/by/2.0), which permits unrestricted use, distribution, and reproduction in any medium, provided the original work is properly cited.
All LTNPs revealed at least one genetic defect in 4 genes, whereas controls revealed it in both 5' LTR/gag and nef genes. Overall genetic defects were significantly higher in LTNPs $(11.4 \%)$ than $4.9 \%$ in controls $(\mathrm{P}<0.001)$. Among the 4 LTNPs, one patient who had taken the least amount of KRG revealed significantly higher proportion of premature stop codons $(5.6 \%)$ than $1.6 \%$ in 3 LTNPs $(\mathrm{P}<0.01)$. There was a significant difference in the frequency of genetic defects between on KRG (10.9\%) and baseline prior to KRG intake $(4.3 \%)(\mathrm{P}<0.01)$. There was a significant correlation between amount of KRG supplied and proportion of genetic defects $(r=0.80, \mathrm{P}<0.05)$. At single gene level, only the nef gene showed a significantly higher frequency of genetic defects in LTNPs (11.5\%) than 3.6\% in controls $(\mathrm{P}<0.01)$.

\section{Conclusion}

These data show the possibility that frequent genetic defects that might be caused by KRG treatment are associated with long-term slow progression.

\section{Published: 19 September 2013}

\section{References}

1. Attele AS, Wu JA, Yuan CS: Ginseng pharmacology: multiple constituents and multiple actions. Biochem Pharmacol 1999, 58:1685-93.

2. Sung $H$, Kang SM, Lee MS, Kim TG, Cho YK: Korean red ginseng slows depletion of CD4T cells in HIV-1-infected patients. Clin Diagn Lab Immunol 2005, 12:497-501.

\section{doi:10.1186/1742-4690-10-S1-P14}

Cite this article as: Cho et al:: Frequent genetic defects in long-term survivors for more than 26 years in the absence of antiretroviral therapy in Korea: its association with ginseng treatment. Retrovirology 2013 10(Suppl 1):P14. 